\title{
Functional characterization of BRCA1 gene variants by mini-gene splicing assay
}

\author{
Ane Y Steffensen ${ }^{1}$, Mette Dandanell ${ }^{1}$, Lars Jønson ${ }^{1}$, Bent Ejlertsen ${ }^{2}$, Anne-Marie Gerdes ${ }^{3}$, Finn C Nielsen ${ }^{1}$ \\ and Thomas vO Hansen ${ }^{\star 1}$
}

\begin{abstract}
Mutational screening of the breast cancer susceptibility gene BRCA1 leads to the identification of numerous pathogenic variants such as frameshift and nonsense variants, as well as large genomic rearrangements. The screening moreover identifies a large number of variants, for example, missense, silent, and intron variants, which are classified as variants of unknown clinical significance owing to the lack of causal evidence. Variants of unknown clinical significance can potentially have an impact on splicing and therefore functional examinations are warranted to classify whether these variants are pathogenic or benign. Here we validate a mini-gene splicing assay by comparing the results of 24 variants with previously published data from RT-PCR analysis on RNA from blood samples/lymphoblastoid cell lines. The analysis showed an overall concordance of $100 \%$. In addition, we investigated $13 B R C A 1$ variants of unknown clinical significance or putative variants affecting splicing by in silico analysis and mini-gene splicing assay. Both the in silico analysis and mini-gene splicing assay classified six BRCA1 variants as pathogenic (c.80+1G $>A, c .132 \mathrm{C}>\mathrm{T}(\mathrm{p} .=), \mathrm{c} .213-1 \mathrm{G}>\mathrm{A}, \mathrm{c} .670+1 \mathrm{delG}, \mathrm{c} .4185+1 \mathrm{G}>\mathrm{A}$, and c.5075-1G $>\mathrm{C})$, whereas six BRCA1 variants were classified as neutral (c.-19-22_-19-21dupAT, c.302-15C > G, c.547+14delG, c.4676-20A $>$ G, c. $4987-21 G>T$, and c.5278 $-14 C>G$ ) and one BRCA1 variant remained unclassified (c. $670+16 G>A)$. In conclusion, our study emphasizes that in silico analysis and mini-gene splicing assays are important for the classification of variants, especially if no RNA is available from the patient. This knowledge is crucial for proper genetic counseling of patients and their family members.
\end{abstract}

European Journal of Human Genetics (2014) 22, 1362-1368; doi:10.1038/ejhg.2014.40; published online 26 March 2014

\section{INTRODUCTION}

Pathogenic germline variants in BRCA1 (MIM no. 113705) predispose carriers to early-onset of breast and ovarian cancer with a risk of $65-71 \%$ for breast cancer and $39-59 \%$ for ovarian cancer by age 70 years. ${ }^{1-3}$ Variants in BRCA1 are scattered throughout the gene, and to date (until 1 October 2013), approximately 14900 variants (listed online at the Breast Cancer Information Core (BIC) database: http://research.nhgri.nih.gov/bic/) have been identified by mutational screening since the cloning and characterization of BRCA1 in the mid-1990s. Many of these variants are pathogenic, such as frameshift and nonsense variants, as well as variants affecting splicing, of which several have been identified in Danish breast and/or ovarian cancer patients. ${ }^{4-9}$ However, a large number of the BRCAl variants, including small in-frame insertions or deletions, missense, silent, and intron variants, are variants of unknown clinical significance (VUS), which makes genetic counseling of patients and their families complicated. To characterize the biological effect of these variants and to provide clinicians with better evidence about treatment and preventive care, functional studies are required. It has been previously shown that a large portion of BRCA1 variants induce splicing defects. ${ }^{10}$ Ideally, RNA from a patient should be examined by RT-PCR analysis to establish if a variant has an effect on splicing. However, in many cases, RNA is not available from the patient. Alternatively, the variant can be examined by mini-gene splicing analysis. ${ }^{11,12}$ To confidently interpret the obtained splicing results, a mini-gene splicing assay should be validated by assessment of the sensitivity and specificity using a panel of variants classified previously. ${ }^{13}$ Here, we report the in silico and functional examination of 37 BRCA1 variants using a mini-gene splicing assay, of which 24 were used to validate the use of the mini-gene splicing assay by comparing data to RT-PCR results using RNA from blood samples/ lymphoblastoid cell lines.

\section{MATERIALS AND METHODS}

\section{Variant nomenclature}

BRCA1 variants are numbered according to the guidelines from the Human Genome Variation Society (http://www.hgvs.org/mutnomen) using NCBI Reference Sequence NG_005905.2, as well as according to GenBank accession number U14680.1, in which the A in the AUG start codon has number 120. All data have been submitted to the Leiden Open Variation database v.2.0 (http://chromium.liacs.nl/LOVD2/cancer/home.php).

\section{In silico analysis}

The following five splice site prediction programs were used to predict the effect of variants on the efficiency of splicing: SpliceSiteFinder (http://www.interactive-biosoftware.com); GeneSplicer (http://www.cbcb. umd.edu/software/GeneSplicer); Splice Site Prediction by Neural Network (http://www.fruitfly.org/seq_tools/splice.html); MaxEntScan (http://genes. mit.edu/burgelab/maxent/Xmaxentscan_scoreseq.html); and Human Splicing Finder (http://www.umd.be/HSF/). The analysis was performed by the integrated software Alamut v.2.3 (http://www.interactive-biosoftware.com)

${ }^{1}$ Center for Genomic Medicine, Rigshospitalet, University of Copenhagen, Copenhagen, Denmark; ${ }^{2}$ Department of Oncology, Rigshospitalet, Copenhagen, Denmark; ${ }^{3}$ Department of Clinical Genetics, Rigshospitalet, Copenhagen, Denmark

*Correspondence: Dr TvO Hansen, Center for Genomic Medicine, Rigshospitalet, University of Copenhagen, Blegdamsvej 9, 2100 Copenhagen, Denmark. Tel: + $4535458972 ;$ Fax: + 45 35454435; E-mail: tvoh@rh.dk

Received 2 December 2013; revised 12 February 2014; accepted 19 February 2014; published online 26 March 2014 
using default settings in all predictions. A variation of more than $10 \%$ in at least two algorithms was considered as having an effect on splicing. ${ }^{12}$

\section{Mini-gene splicing assay}

Wild-type BRCA1 exons (2, 3, 5, 6, 7, 8, 9, 10, 12, 13, 14, 15, 16, 17, 18, 19, 20, 21,22 , and 23 ) along with at least $200 \mathrm{bp}$ of $5^{\prime}$ and $3^{\prime}$ intronic sequences were PCR amplified from human genomic DNA using Phusion DNA polymerase (Roche, Hvidovre, Denmark) and forward and reverse primers carrying restriction sites for either EcoRI, BamHI, NotI, or XhoI (primer sequences are available on request). PCR products were subcloned into the pSPL3 vector. ${ }^{14}$ All constructs were verified by sequencing. Single-nucleotide substitutions or deletions were introduced using Finnzymes' Phusion HighFidelity DNA polymerase according to the accompanying instructions. Wildtype and mutant constructs were transfected in duplicate into COS-7 cells as described recently, ${ }^{6}$ to account for differences in transfection efficiencies. Cells were harvested after $48 \mathrm{~h}$ and total RNA was extracted using Trizol reagent (Invitrogen, Naerum, Denmark). cDNA was synthesized using $1 \mu \mathrm{g}$ of total RNA, M-MuLV reverse transcriptase polymerase (New England Biolabs, Hitchin, UK), and $20 \mu \mathrm{m}$ of nucleotide oligo $(\mathrm{dT})_{15}$ primer. cDNA was amplified with Phusion DNA polymerase using the primers dUSD2 $\left(5^{\prime}\right.$-TCT GAGTCACCTGGACAACC- ${ }^{\prime}$ ) and dUSA4 (5'-ATCTCAGTGGTATTTGTGAG C- $\left.3^{\prime}\right)$. PCR products were separated by electrophoresis on a $1 \%$ agarose gel containing ethidium bromide. Each DNA band was gel purified using GE Healthcare's (Bronby, Denmark) Illustra GFX PCR DNA and gel band purification kit and sequenced with dUSD2 and dUSA4 primers.

\section{RESULTS}

We have previously used a mini-gene splicing assay to examine the effect of $B R C A 1 / B R C A 2$ variants on splicing. ${ }^{5,6,9}$ To validate this assay, 24 variants previously examined by RT-PCR using RNA from blood samples/lymphoblastoid cell lines were introduced into the pSPL3 vector (Figure 1a). The variants are located at or near splice acceptor or donor sites in BRCA1. Variants present in BRCA1 exon 11 were excluded as we were unable to achieve the expression of wild-type exon 11, probably owing to its large size. However, variants in the exon $2,3,5,6,7,8,9,10,13,14,15,16,17,19,20,21,22$, and 23 vector constructs were examined in the validation setup (Supplementary Figures 1A-U). ${ }^{9,11,15-29}$ As summarized in Table 1, all major effects identified in the RT-PCR analyses on RNA from blood samples/lymphoblastoid cell lines were also identified by the mini-gene splicing assays. Thus, there is $100 \%$ concordance between the mini-gene splicing assay results and the results from RNA from blood samples/lymphoblastoid cell lines, taking into account that the position of the cryptic splice sites activated by two BRCA1 variants $(\mathrm{c} .5074+1 \mathrm{G}>\mathrm{T}$ and c.5277 $+1 \mathrm{G}>\mathrm{A}$ ) were wrongly annotated in the original publications but are identical to our findings upon sequence comparison..$^{22,24}$ Moreover, in our hands, a minor increased skipping of exon 17 was observed for the c.5074 $+6 \mathrm{C}>\mathrm{G}$ variant that was not described in the literature, although splicing data were not presented in the studies. ${ }^{21,28}$

Following this successful validation of the mini-gene splicing assay, we investigated 13 BRCA1 variants not previously examined by functional assays (Table 2). First, the potential pathogenicity of the variants was investigated using five different in silico splice site prediction programs, which predict changes in splice site strength. The applicable threshold was a variation between the wild-type and the variant score of more than $10 \%$ in at least two different algorithms. ${ }^{12}$ According to this criterion, seven BRCA1 variants, c. $80+1 \mathrm{G}>\mathrm{A}, \quad$ c. $132 \mathrm{C}>\mathrm{T}(\mathrm{p} .=)$, c. $213-1 \mathrm{G}>\mathrm{A}, \quad$ c. $302-15 \mathrm{C}>\mathrm{G}$, c. $670+1$ delG, c. $4185+1 \mathrm{G}>\mathrm{A}$, and c.5075-1G $>$ C (Table 2), were suggested to have an effect on splicing, whereas no splicing alterations were predicted for the remaining six variants (c.-19-22_-19-21dupAT, c. $547+14$ delG, c. $670+16 \mathrm{G}>$ A, c. $4676-20 \mathrm{~A}>\mathrm{G}$, c. $4987-21 \mathrm{G}>\mathrm{T}$, and c. $5278-14 \mathrm{C}>\mathrm{G}$ ). The functional effects of all 13 BRCA1 variants were subsequently examined by mini-gene splicing assays. Each construct was transfected into COS-7 cells in duplicate and cells were harvested. Then, mRNA was purified, analyzed by RT-PCR, and finally PCR products were visualized on $1 \%$ agarose gels (Figure $1 \mathrm{~b}-\mathrm{m}$ ). In accordance with the in silico results, six BRCA1 variants $($ c. $80+1 \mathrm{G}>\mathrm{A}, \quad$ c. $132 \mathrm{C}>\mathrm{T} \quad(\mathrm{p} .=), \quad$ c. $213-1 \mathrm{G}>\mathrm{A}, \quad$ c. $670+1 \mathrm{delG}$, c. $4185+1 \mathrm{G}>\mathrm{A}$, and $\mathrm{c} .5075-1 \mathrm{G}>\mathrm{C}$ ) revealed the presence of alternative gel bands compared with the corresponding wild types. The wild-type BRCA1 exon 2 construct generated one transcript comprising the expected $276 \mathrm{bp}$, whereas the c. $80+1 \mathrm{G}>\mathrm{A}$ mutant yielded one strong band of $177 \mathrm{bp}$ lacking exon 2 (Figure $1 \mathrm{~b}$ ). Wild-type BRCA1 exon 3 generated one transcript at the expected $231 \mathrm{bp}$, whereas the $\mathrm{c} .132 \mathrm{C}>\mathrm{T}(\mathrm{p} .=)$ mutant resulted in one strong band of $227 \mathrm{bp}$ excluding the last four bases of exon 3 (Figure 1c). Wild-type BRCA1 exon 6 generated one transcript at the expected size of $266 \mathrm{bp}$, whereas the c.213-1G>A mutant resulted in one strong band of $325 \mathrm{bp}$, including $59 \mathrm{bp}$ of intron 5 (Figure 1d). Wild-type $B R C A 1$ exon 10 revealed the presence of two bands, one of $254 \mathrm{bp}$ including exon 10 and one of $177 \mathrm{bp}$ excluding exon 10 . The c. $670+1$ delG mutant resulted in a 253-bp transcript lacking 1 bp of exon 10 (Figure 1e). Wild-type BRCA1 exon 12 revealed the presence of one band at the expected size of $266 \mathrm{bp}$, whereas the c. $4185+1 \mathrm{G}>\mathrm{A}$ mutant resulted in one strong band of $177 \mathrm{bp}$ lacking exon 12 (Figure 1f). Wild-type BRCA1 exon 18 exhibited one band with the expected size of $255 \mathrm{bp}$, whereas the c.5075-1G>C mutant revealed a single band of $177 \mathrm{bp}$ lacking exon 18 (Figure $1 \mathrm{~g}$ ). In contrast, the c.-19-22_-19-21dupAT (Figure 1h), c.302-15C > G (Figure 1i), c. $547+14$ delG (Figure 1j), c.4676-20A $>\mathrm{G}$ (Figure 1k), c. $4987-21 \mathrm{G}>\mathrm{T}$ (Figure 11), and c.5278-14C>G (Figure $1 \mathrm{~m}$ ) variants showed no band size or intensity differences between wild-type and mutant constructs. This was in agreement with the in silico data except for the c. $302-15 \mathrm{C}>\mathrm{G}$ variant. The c. $670+16 \mathrm{G}>\mathrm{A}$ variant (Figure 1e), however, appeared to make the consensus splice donor site stronger. Our results revealed a major band of $254 \mathrm{bp}$ including exon 10 and a minor 177-bp band lacking exon 10, which is the opposite to the wild-type pattern. In all cases, the findings were verified by sequencing of the gel bands. All variants were classified according to the 5-Tier splicing classification scheme proposed recently (Tables 1 and 2). ${ }^{30,31}$

\section{DISCUSSION}

To ensure patients with hereditary breast cancer receive optimal genetic counseling and thereby preventive care, it is important to classify all identified BRCA1 sequence variants. ${ }^{32}$ It has previously been established that all variant types in BRCA1 can lead to splicing abnormalities, ${ }^{10}$ and therefore it is important to investigate all variants at the RNA level before classification. Splicing analysis is preferably carried out using RNA from blood samples/lymphoblastoid cell lines. However, in many cases, RNA is not available from the patient. Alternatively, the variant can be examined by mini-gene splicing analysis, which has previously been shown to be a valid method for investigating the impact of variants on the splicing pattern. ${ }^{11,12}$ The mini-gene splicing assay validation performed in the current study showed a $100 \%$ concordance with the 24 BRCA1 variants previously classified using RT-PCR analysis on RNA from blood samples/lymphoblastoid cell lines and therefore supports the previous findings.

The position of two of the cryptic splice sites activated was incorrectly annotated in the original publications. The BRCA1 
a

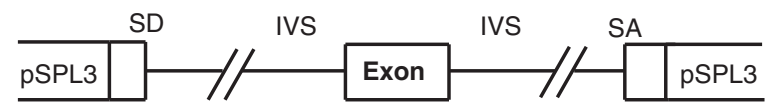

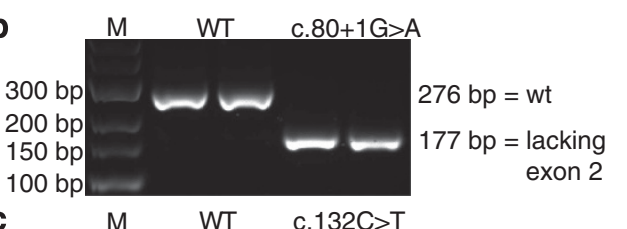
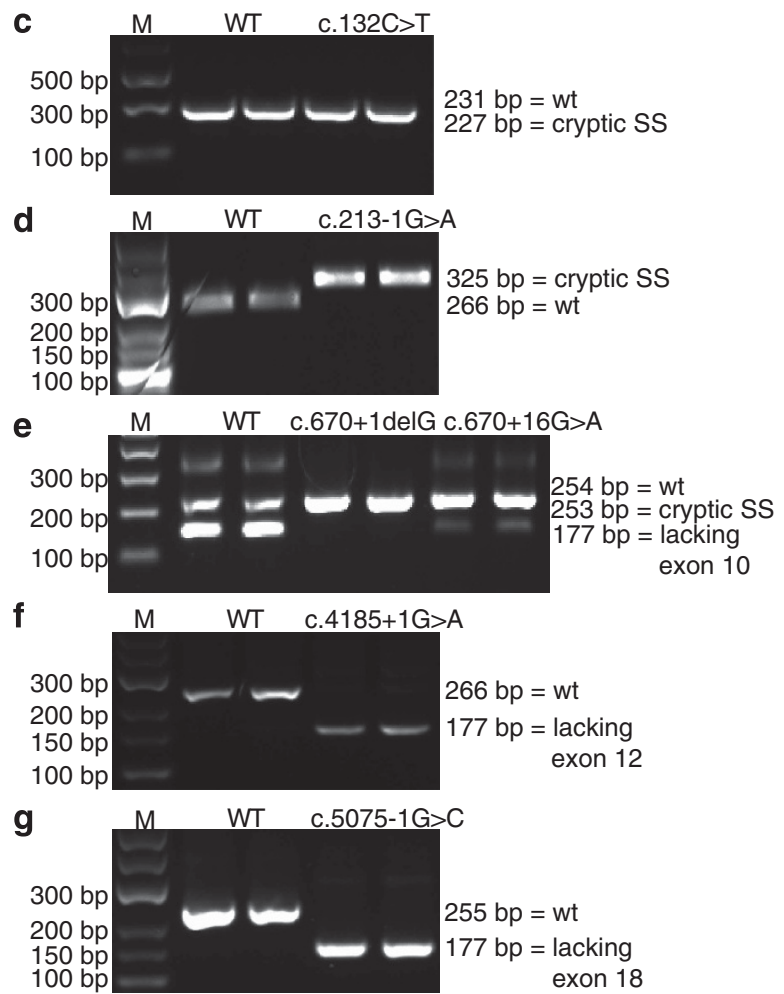
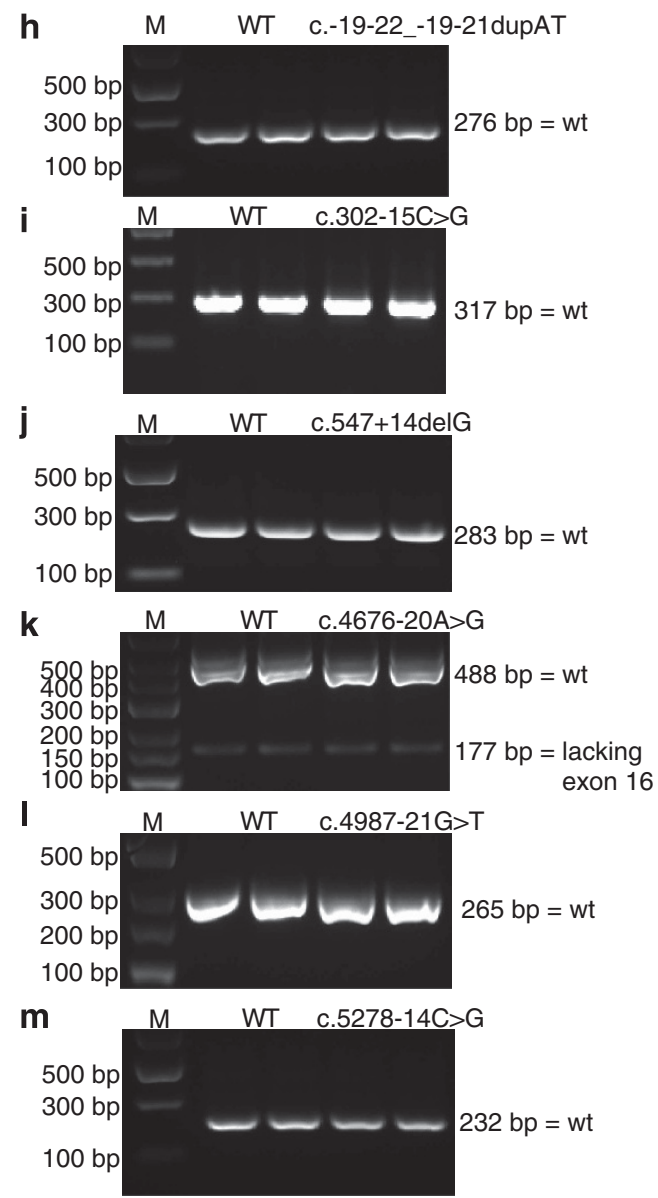

Figure 1 Mini-gene splicing analysis of BRCA1 VUS/putative splice variants. COS-7 cells were transfected with wild-type or mutant vectors in duplicate. Total RNA was isolated, RT-PCR analysis was performed, and PCR products were separated by agarose gel electrophoresis and visualized by ethidium bromide staining. The sizes of the DNA marker $(M)$ are indicated to the left. All PCR products were verified by sequencing. (a) The different exons were cloned into the pSPL3 vector. IVS, intervening sequence; SA, splice acceptor sit; SD, splice donor site. (b) The BRCA1 c.80+1G $>A$ variant resulted in a 177-bp band corresponding to a transcript lacking exon 2. (c) The BRCA1 c.132C > T variant produced a 227-bp PCR product by usage of a cryptic splice donor site $4 \mathrm{bp}$ within exon 3. (d) The BRCA1 c.213-1G $>$ A variant resulted in a 325-bp transcript by usage of a cryptic splice acceptor site $59 \mathrm{bp}$ within intron 5. (e) The BRCA1 c.670+1delG variant produced a 253-bp transcript by usage of a cryptic splice donor site $1 \mathrm{bp}$ within exon 10, whereas the BRCA1 c.670+16G>A variant produced a 254-bp PCR product that corresponds to wild-type exon 10 , although the intensity of the bands was changed. (f) The BRCA1 c.4185+1G $>$ A variant resulted in a 177-bp band corresponding to a transcript lacking exon 12. (g) The BRCA1 c.5075-1G $>$ C variant resulted in a 177-bp band corresponding to a transcript lacking exon 18. (h) The BRCA1 c.-19-22_-19-21dupAT variant produced a 276-bp band corresponding to wild-type exon 2 (unaltered splicing). (i) The BRCA1 c.302-15C $>$ G variant resulted in a 317-bp product corresponding to wild-type exon 7 (unaltered splicing). (j) The BRCA1 c.547+14delG variant produced a 283-bp PCR product that corresponds to wild-type exon 8 (unaltered splicing). (k) The BRCA1 c.4676-20A $>$ G variant produced a 488-bp transcript corresponding to wild-type exon 16 and a weak 177-bp PCR product that corresponds to a transcript lacking exon 16. (I) The BRCA1 c.4987-21G $>$ T variant produced a 265-bp PCR product that corresponds to wild-type exon 17 (unaltered splicing). (m) The BRCA1 c.5278-14C>G variant produced a 232-bp PCR product that corresponds to wild-type exon 21 (unaltered splicing).

c. $5074+1 \mathrm{G}>\mathrm{T}$ variant was reported to result in retention of $150 \mathrm{bp}$ of intron $17 .^{22}$ Our mini-gene splicing assay showed that $153 \mathrm{bp}$ of intron 17 were included in the transcript, which is in agreement with the sequence reported in the original publication. Moreover, the BRCA1 c. $5277+1 \mathrm{G}>\mathrm{A}$ variant was reported to result in an outof-frame inclusion of $85 \mathrm{bp}$ of intron 20 , leading to a premature stop codon. ${ }^{24}$ Our mini-gene splicing assay results revealed that the variant induced an in-frame inclusion of $87 \mathrm{bp}$ of intron 20, which also is in agreement with the sequence reported in the original publication. Therefore, the variant results in the inclusion of an extra 29 amino acids in the protein instead of a premature stop codon, indicating that the variant should be reclassified as a VUS. In addition, our validation analysis revealed that the BRCA1 c.5074 $+6 \mathrm{C}>\mathrm{G}$ variant showed a minor increase in the transcripts lacking exon 17 compared with the wild type. In two previous studies, this variant was classified as neutral based on RT-PCR using RNA from blood samples. ${ }^{21,28}$ Splicing data were not presented in these publications, and as they used RNA purified from blood samples, the weak band observed here could have been degraded by nonsense-mediated decay. On the basis of the partial skipping of exon 17, we classify this variant as a VUS. 
Table 1 Validation of the mini-gene splicing assay investigating 24 BRCA1 variants previously examined by RT-PCR analysis on RNA from blood samples or LCLs

\begin{tabular}{|c|c|c|c|c|c|c|c|}
\hline $\begin{array}{l}\text { NT change } \\
\text { (HGVS) }\end{array}$ & NT change (BIC) & Location & $\begin{array}{l}\text { Effect observed in } \\
\text { mini-gene assay }\end{array}$ & $\begin{array}{l}\text { Effect observed in RT-PCR } \\
\text { analysis on RNA from blood } \\
\text { samples or LCLs }\end{array}$ & RNA change (HGVS) & References & $\begin{array}{l}\text { 5-Tier } \\
\text { splicing } \\
\text { classification }^{\mathrm{a}}\end{array}$ \\
\hline c. $-19-10 \mathrm{~T}>\mathrm{C}$ & $101-10 \mathrm{~T}>\mathrm{C}$ & Intron 1 & No aberration & No aberration & r. $[=]$ & 15 & Class 2 \\
\hline c. $81-14 \mathrm{C}>\mathrm{T}$ & $200-14 C>T$ & Intron 2 & No aberration & No aberration & $r .[=]$ & 16,28 & Class 2 \\
\hline c. $134+3 A>C$ & $253+3 A>C$ & Intron 3 & In-frame skipping of exon 3 & In-frame skipping of exon 3 & r.[81_134del] & 16 & Class 5 \\
\hline c. $212+3 A>G$ & $331+3 A>G$ & Intron 5 & $\begin{array}{l}\text { Increased in-frame skipping } \\
\text { of exon } 5 \text { and out-of-frame } \\
\text { skipping of the last } 22 \\
\text { nucleotides of exon } 5\end{array}$ & $\begin{array}{l}\text { In-frame skipping of exon } 5 \text { and } \\
\text { out-of-frame skipping of the last } \\
22 \text { nucleotides of exon } 5\end{array}$ & r.[135_212del, 191_212del] & $16,18,28$ & Class 5 \\
\hline c. $301+7 \mathrm{G}>\mathrm{A}$ & $420+7 G>A$ & Intron 6 & No aberration & No aberration & r. $[=]$ & 28 & Class 2 \\
\hline c. $441+1 G>A$ & $560+1 G>A$ & Intron 7 & $\begin{array}{l}\text { Skipping of exon } 7 \text { and } \\
\text { out-of-frame deletion of } \\
62 \text { bp of exon } 7\end{array}$ & $\begin{array}{l}\text { Out-of-frame deletion of } 62 \mathrm{bp} \text { of } \\
\text { exon } 7\end{array}$ & r.[302_441del, 380_441del] & 18 & Class 5 \\
\hline c. $547+2 \mathrm{~T}>\mathrm{A}$ & $666+2 \mathrm{~T}>\mathrm{A}$ & Intron 8 & Skipping of exon 8 & Skipping of exon 8 & r.[442_547del] & 27,28 & Class 5 \\
\hline c. $593+8 A>G$ & $712+8 A>G$ & Intron 9 & No aberration & No aberration & r. $[=]$ & 18 & Class 2 \\
\hline c. $594-2 A>C$ & $713-2 A>C$ & Intron 9 & $\begin{array}{l}\text { Skipping of exon } 10^{\mathrm{b}} \text { and } \\
\text { in-frame retention of } 21 \mathrm{bp} \\
\text { of intron } 9\end{array}$ & $\begin{array}{l}\text { Skipping of exon } 10 \text { and in-frame } \\
\text { retention of } 21 \mathrm{bp} \text { of intron } 9 \text { (as } \\
\text { well as other deletions identified } \\
\text { with primers spanning more } \\
\text { exons) }\end{array}$ & $\begin{array}{l}\text { r.[594_670del, 593_594ins } \\
\text { 594-21_594-1; 594-2a >c] }\end{array}$ & 24,29 & Class 3 \\
\hline c. $670+8 \mathrm{C}>\mathrm{T}$ & $789+8 \mathrm{C}>\mathrm{T}$ & Intron 10 & $\begin{array}{l}\text { Increased inclusion of exon } \\
10\end{array}$ & $\begin{array}{l}\text { Increased inclusion of exon } 10 \\
\text { (and 9) }\end{array}$ & $r .[=]$ & 11 & Class 3 \\
\hline c. $4357+1 G>A$ & $4476+1 G>A$ & Intron 13 & Skipping of exon 13 & Skipping of exon 13 & r.[4186_4357del] & 9 & Class 5 \\
\hline c. $4484+1 \mathrm{G}>\mathrm{A}$ & $4603+1 G>A$ & Intron 14 & Skipping of exon 14 & Skipping of exon 14 & r.[4358_4484del] & 20,28 & Class 5 \\
\hline c. $4484+14 A>G$ & $4603+14 A>G$ & Intron 14 & No aberration & No aberration & $r .[=]$ & 28 & Class 2 \\
\hline c. $4675+1 \mathrm{G}>\mathrm{A}$ & $4794+1 G>A$ & Intron 15 & Skipping of exon 15 & $\begin{array}{l}\text { Skipping of exon } 15 \text { (as well as } \\
\text { other smaller deletions) }\end{array}$ & r.[4485_4675del] & 26 & Class 4 \\
\hline c. $4986+6 \mathrm{~T}>\mathrm{G}$ & $5105+6 \mathrm{~T}>\mathrm{G}$ & Intron 16 & $\begin{array}{l}\text { Out-of-frame retention of } \\
65 \mathrm{bp} \text { of intron } 16 \text { and } \\
\text { increased skipping of } \\
\text { exon } 16\end{array}$ & $\begin{array}{l}\text { Out-of-frame retention of } 65 \mathrm{bp} \text { of } \\
\text { intron } 16\end{array}$ & $\begin{array}{l}\text { r.[4986_4987ins4986 + 1_4986+65; } \\
4986+6 u>g, 4676 \_4986 \text { del] }\end{array}$ & 18 & Class 5 \\
\hline$c .5074+1 G>T$ & $5193+1 G>T$ & Intron 17 & $\begin{array}{l}\text { Retention of } 153 \mathrm{bp} \text { of } \\
\text { intron } 17 \text { and skipping of } \\
\text { exon } 17\end{array}$ & Retention of $153 \mathrm{bp}$ of intron 17 & $\begin{array}{l}\text { r.[5074_5075ins5074+1_5075+153; } \\
\left.5074+1 \mathrm{~g}>\mathrm{u}, 4987 \_5074 \mathrm{del}\right]\end{array}$ & 22 & Class 5 \\
\hline c. $5074+6 C>G$ & $5193+6 C>G$ & Intron 17 & $\begin{array}{l}\text { Minor increased skipping of } \\
\text { exon } 17\end{array}$ & No aberration (data not shown) & r.[4987_5074del] & 21,28 & Class 3 \\
\hline c. $5153-1 \mathrm{G}>\mathrm{A}$ & $5272-1 \mathrm{G}>\mathrm{A}$ & Intron 18 & $\begin{array}{l}\text { Out-of-frame deletion of } 1 \\
\text { bp of exon } 19\end{array}$ & $\begin{array}{l}\text { Out-of-frame deletion of } 1 \text { bp of } \\
\text { exon } 19\end{array}$ & r.[5153del] & 23 & Class 5 \\
\hline c. $5277+1 \mathrm{G}>\mathrm{A}$ & $5396+1 G>A$ & Intron 20 & $\begin{array}{l}\text { In-frame retention of } 87 \mathrm{bp} \\
\text { of intron } 20 \text { and skipping of } \\
\text { exon } 20\end{array}$ & $\begin{array}{l}\text { In-frame retention of } 87 \mathrm{bp} \text { of } \\
\text { intron } 20 \text { and skipping of } \\
\text { exon } 20\end{array}$ & $\begin{array}{l}\text { r.[5277_5278ins5277+1_5277+87; } \\
\left.5277+1 \mathrm{~g}>\mathrm{a}, 5194 \_5277 \mathrm{del}\right]\end{array}$ & 24 & Class 5 \\
\hline c. $5332+1 \mathrm{G}>\mathrm{A}$ & $5451+1 G>A$ & Intron 21 & Skipping of exon 21 & Skipping of exon 21 & r.[5278_5332del] & 27 & Class 5 \\
\hline c. $5406+1 \mathrm{G}>\mathrm{A}$ & $5525+1 G>A$ & Intron 22 & Skipping of exon 22 & Skipping of exon 22 & r.[5333_5406del] & 28 & Class 5 \\
\hline c. $5406+8 T>C$ & $5525+8 T>C$ & Intron 22 & No aberration & No aberration & $r .[=]$ & 11,28 & Class 2 \\
\hline c. $5406+33 \mathrm{~A}>\mathrm{T}$ & $5525+33 A>T$ & Intron 22 & No aberration & No aberration & $r \cdot[=]$ & 28 & Class 2 \\
\hline c. $5467+1 \mathrm{G}>\mathrm{A}$ & $5586+1 \mathrm{G}>\mathrm{A}$ & Intron 23 & Skipping of exon 23 & Skipping of exon 23 & r.[5407_5467del] & 25 & Class 5 \\
\hline
\end{tabular}

Abbreviation: LCL, lymphoblastoid cell line.

aThe 5-Tier splicing classification is based on Whiley et al. ${ }^{29}$ and Spurdle et al. ${ }^{30}$

bAlso observed in wild-type control.

We also examined the effect of 13 (12 intronic and one exonic) uncharacterized $B R C A 1$ variants on splicing by in silico analysis and mini-gene splicing assay. The in silico analysis predicted alterations in the splicing pattern for seven BRCA1 variants $(\mathrm{c} .80+1 \mathrm{G}>\mathrm{A}$, c. $132 \mathrm{C}>\mathrm{T}(\mathrm{p} .=)$, c. $213-1 \mathrm{G}>\mathrm{A}$, c. $302-15 \mathrm{C}>\mathrm{G}$, c. $670+1 \mathrm{delG}$, c. $4185+1 \mathrm{G}>\mathrm{A}$, and c.5075-1G>C), whereas six BRCA1 variants (c.-19-22_-19-21dupAT, c.547+14delG, c.670+16G $>$ A, c. $4676-20 \mathrm{~A}>\mathrm{G}, \quad$ c. $4987-21 \mathrm{G}>\mathrm{T}$, and c.5278-14C>G) were predicted to have no effect on splicing. However, mini-gene splicing analysis revealed that the $c .302-15 C>G$ variant had no effect on splicing, suggesting that the criterion used ( $>10 \%$ difference between wild-type and mutant scores in at least two programs) results in falsepositive predictions as shown previously. ${ }^{12}$

The mini-gene splicing analysis revealed that three of the six deleterious variants resulted in the use of a cryptic splice site. The silent variant $\mathrm{c} .132 \mathrm{C}>\mathrm{T}(\mathrm{p} .=)$ was predicted to introduce a new strong splice site located $4 \mathrm{bp}$ upstream from the consensus splice site, which was confirmed by the mini-gene splicing assay. Moreover, the c.213-1G $>$ A variant destroyed the exon 5 consensus acceptor splice site, resulting in the use of a cryptic splice site located 59 bp upstream 


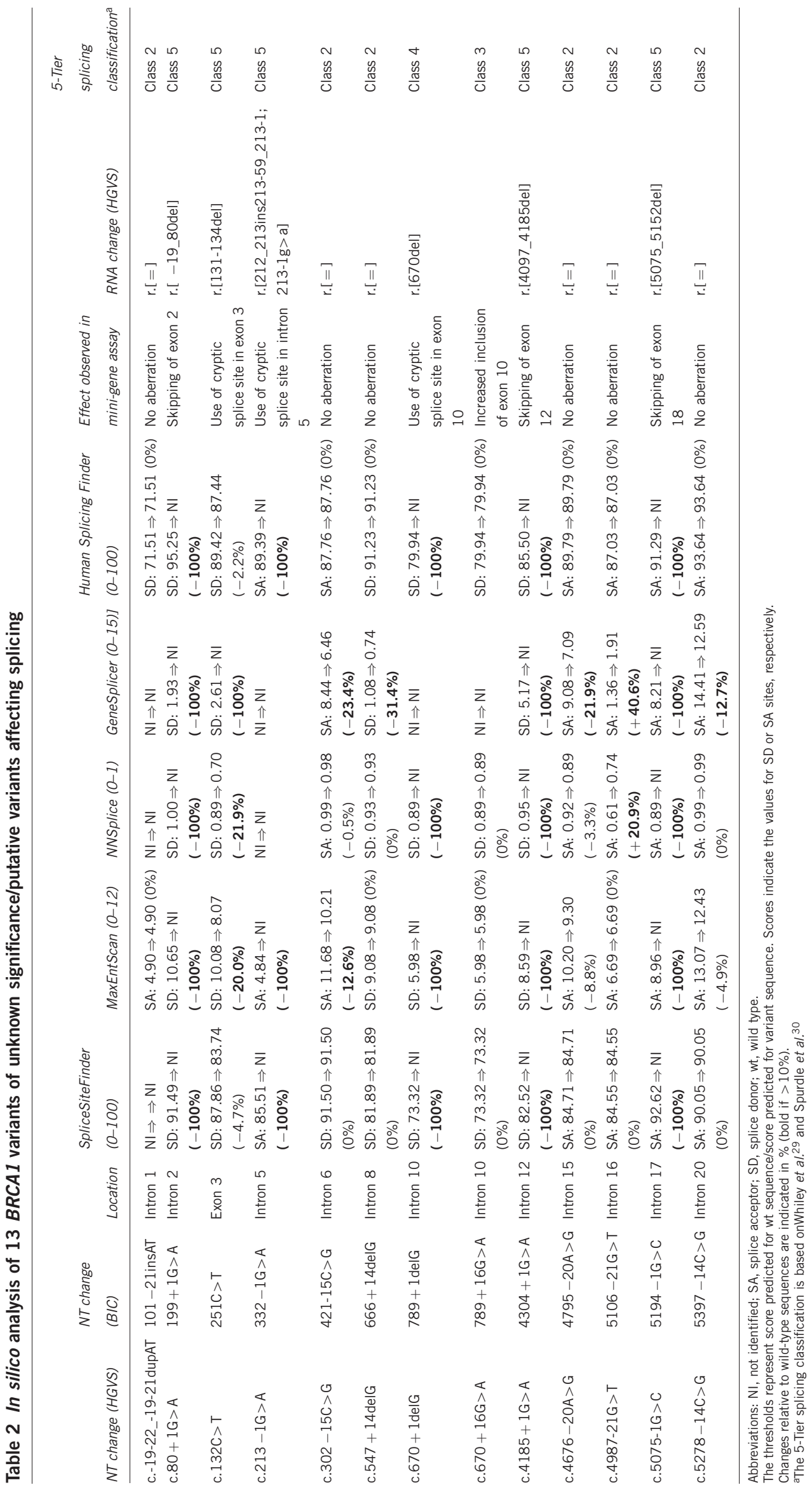


of exon 5. This is in agreement with another variant $($ c. $213-11 \mathrm{~T}>\mathrm{G})$, which uses the same cryptic splice site. ${ }^{27}$ Finally, the c.670+1delG variant disrupted the exon 10 consensus donor splice site, creating a new splice site using the last base of exon 10. All three variants ultimately lead to the disruption of the reading frame and are classified as pathogenic. Interestingly, 10 of the 20 pathogenic variants investigated in the present study result in the use of a cryptic splice site. This emphasizes the importance of functional evaluation of all potential variants affecting splicing, including variants in the consensus splice sites, as cryptic splice sites can result in small inframe deletions or insertions that may not be pathogenic. The analysis moreover emphasizes the need for sequencing of all gel bands observed in the mini-gene splicing assay as some variants induce the use of cryptic splice sites in close proximity of the splice donor or acceptor sites (eg, c.132C $>$ T and c.5153-1G > A).

The mini-gene splicing assay moreover revealed that the three remaining variants - c. $80+1 \mathrm{G}>\mathrm{A}, \quad \mathrm{c} .4185+1 \mathrm{G}>\mathrm{A}$, and c.5075-1G>C - resulted in skipping of exons 2, 12, and 18, respectively. All three variants result in disruption of the reading frame and are classified as pathogenic.

Furthermore, our results showed that the BRCA1 c. $670+16 \mathrm{G}>\mathrm{A}$ variant induced almost complete inclusion of exon 10 - an exon known to be involved in alternative splicing. The BRCA1 c. $670+8 \mathrm{C}>\mathrm{T}$ variant has previously been found, by both mini-gene splicing assay and RT-PCR using RNA from blood samples, ${ }^{11}$ to result in complete inclusion of exons 9 and 10. Currently, knowledge is lacking regarding the functions of the different $B R C A 1$ isoforms and their roles in cancer protection. Some experiments indicate that the balance between the different isoforms is important, whereas others have shown that the balance between the isoforms changes during the cell cycle and differs between different tissues. Until a better understanding of the different isoforms is achieved, variants affecting the ratio of splicing isoforms cannot be classified properly. ${ }^{33}$

In conclusion, based on a validated mini-gene splicing assay, we classified six BRCA1 variants $(\mathrm{c} .80+1 \mathrm{G}>\mathrm{A}, \mathrm{c} .132 \mathrm{C}>\mathrm{T} \quad(\mathrm{p} .=)$ ), c. $213-1 \mathrm{G}>\mathrm{A}, \mathrm{c} .670+1 \mathrm{delG}, \mathrm{c} .4185+1 \mathrm{G}>\mathrm{A}$, and c.5075-1G $>\mathrm{C}$ ) as pathogenic, whereas six BRCA1 variants (c.-19-22_-19-21dupAT, c. $302-15 \mathrm{C}>\mathrm{G}$, c. $547+14 \mathrm{delG}$, c. $4676-20 \mathrm{~A}>\mathrm{G}$, c. $4987-21 \mathrm{G}>\mathrm{T}$, and c.5278-14C >G) were classified as neutral. One variant $(c .670+16 \mathrm{G}>\mathrm{A})$ was shown to increase the inclusion of exon 10 compared with the wild type and was therefore classified as a VUS. This study supports the use of in silico prediction tools and mini-gene splicing assays in the assessment of the pathogenicity of BRCA1 variants.

\section{CONFLICT OF INTEREST}

The authors declare no conflict of interest.

\section{ACKNOWLEDGEMENTS}

We thank Stine Østergaard for technical assistance. This study was supported by the Familien Hede Nielsens Foundation and the Neye Foundation.

\section{AUTHOR CONTRIBUTIONS}

The study was conceived and designed by $\mathrm{TvOH}$. Patients were recruited by AMG and BE and interpretation of variants was performed by AYS, LJ, FCN, and $\mathrm{TvOH}$. The mini-gene splicing assay was performed by AYS and MD, whereas in silico analyses were performed by AYS, MD, and TvOH. The manuscript was drafted by AYS and TvOH. All authors approved the final version of the manuscript.
1 Antoniou A, Pharoah PD, Narod S et al: Average risks of breast and ovarian cancer associated with BRCA1 or BRCA2 mutations detected in case Series unselected for family history: a combined analysis of 22 studies. Am J Hum Genet 2003; 72 : 1117-1130.

2 King MC, Marks JH, Mandell JB: Breast and ovarian cancer risks due to inherited mutations in BRCA1 and BRCA2. Science 2003; 302: 643-646.

3 van der Kolk DM, de Bock GH, Leegte BK et al: Penetrance of breast cancer, ovarian cancer and contralateral breast cancer in BRCA1 and BRCA2 families: high cancer incidence at older age. Breast Cancer Res Treat 2010; 124: 643-651.

4 Thomassen M, Hansen TV, Borg A et al: BRCA1 and BRCA2 mutations in Danish families with hereditary breast and/or ovarian cancer. Acta Oncol 2008; 47: 772-777.

5 Hansen TV, Bisgaard ML, Jonson L et al: Novel de novo BRCA2 mutation in a patient with a family history of breast cancer. BMC Med Genet 2008; 9: 58.

6 Hansen TV, Steffensen AY, Jonson L, Andersen MK, Ejlertsen B, Nielsen FC: The silent mutation nucleotide $744 \mathrm{G}->$ A, Lys172Lys, in exon 6 of BRCA2 results in exon skipping. Breast Cancer Res Treat 2010; 119: 547-550.

7 Hansen T, Jonson L, Albrechtsen A, Andersen MK, Ejlertsen B, Nielsen FC: Large BRCA1 and BRCA2 genomic rearrangements in Danish high risk breast-ovarian cancer families. Breast Cancer Res Treat 2009; 115: 315-323.

8 Steffensen AY, Jonson L, Ejlertsen B, Gerdes AM, Nielsen FC, Hansen TV: Identification of a Danish breast/ovarian cancer family double heterozygote for BRCA1 and BRCA2 mutations. Fam Cancer 2010; 9: 283-287.

9 Thomassen M, Blanco A, Montagna $\mathrm{M}$ et al: Characterization of BRCA1 and BRCA2 splicing variants: a collaborative report by ENIGMA consortium members. Breast Cancer Res Treat 2012; 132: 1009-1023.

10 Sanz DJ, Acedo A, Infante M et al: A high proportion of DNA variants of BRCA1 and BRCA2 is associated with aberrant splicing in breast/ovarian cancer patients. Clin Cancer Res 2010; 16: 1957-1967.

11 Bonnet C, Krieger S, Vezain M et al: Screening BRCA1 and BRCA2 unclassified variants for splicing mutations using reverse transcription PCR on patient RNA and an ex vivo assay based on a splicing reporter minigene. J Med Genet 2008; 45: 438-446.

12 Thery JC, Krieger S, Gaildrat P et al: Contribution of bioinformatics predictions and functional splicing assays to the interpretation of unclassified variants of the BRCA genes. Eur J Hum Genet 2011; 19: 1052-1058.

13 Millot GA, Carvalho MA, Caputo SM et al: A guide for functional analysis of BRCA1 variants of uncertain significance. Hum Mutat 2012; 33: 1526-1537.

14 Church DM, Stotler CJ, Rutter JL, Murrell JR, Trofatter JA, Buckler AJ: Isolation of genes from complex sources of mammalian genomic DNA using exon amplification. Nat Genet 1994; 6: 98-105.

15 Fetzer S, Tworek HA, Piver MS, DiCioccio RA: Classification of IVS1-10T->C as a polymorphism of BRCA1. Cancer Genet Cytogenet 1999; 113: 58-64.

16 Claes K, Poppe B, Machackova E et al: Differentiating pathogenic mutations from polymorphic alterations in the splice sites of BRCA1 and BRCA2. Genes Chromosomes Cancer 2003; 37: 314-320.

17 Claes K, Vandesompele J, Poppe B et al: Pathological splice mutations outside the invariant $A G / G T$ splice sites of BRCA1 exon 5 increase alternative transcript levels in the 5' end of the BRCA1 gene. Oncogene 2002; 21: 4171-4175.

18 Chen X, Truong TT, Weaver J et al: Intronic alterations in BRCA1 and BRCA2: effect on mRNA splicing fidelity and expression. Hum Mutat 2006; 27: 427-435.

19 Dosil V, Tosar A, Canadas C et al: Alternative splicing and molecular characterization of splice site variants: BRCA1 c.591C > T as a case study. Clin Chem 2010; 56: 53-61.

20 Perkowska M, Brozek I, Wysocka B et al: BRCA1 and BRCA2 mutation analysis in breast-ovarian cancer families from northeastern Poland. Hum Mutat 2003; 21 : 553-554.

21 Bonatti F, Pepe C, Tancredi M et al: RNA-based analysis of BRCA1 and BRCA2 gene alterations. Cancer Genet Cytogenet 2006; 170: 93-101.

22 Brose MS, Volpe P, Paul K et al: Characterization of two novel BRCA1 germ-line mutations involving splice donor sites. Genet Test 2004; 8: 133-138.

23 Beristain E, Martinez-Bouzas C, Guerra I et al: Differences in the frequency and distribution of BRCA1 and BRCA2 mutations in breast/ovarian cancer cases from the Basque country with respect to the Spanish population: implications for genetic counselling. Breast Cancer Res Treat 2007; 106: 255-262.

24 Tesoriero AA, Wong EM, Jenkins MA et al: Molecular characterization and cancer risk associated with BRCA1 and BRCA2 splice site variants identified in multiple-case breast cancer families. Hum Mutat 2005; 26: 495.

25 Laskie OK, DiCioccio RA, McGuire V, Whittemore AS: A BRCA1 variant, IVS23 $+1 \mathrm{G}->$ A, causes abnormal RNA splicing by deleting exon 23. Cancer Genet Cytogenet 2001; 127: 188-190.

26 Machackova E, Foretova L, Lukesova M et al: Spectrum and characterisation of BRCA1 and BRCA2 deleterious mutations in high-risk Czech patients with breast and/or ovarian cancer. BMC Cancer 2008; 8: 140 .

27 Colombo M, De VG, Caleca L et al: Comparative in vitro and in silico analyses of variants in splicing regions of BRCA1 and BRCA2 genes and characterization of novel pathogenic mutations. PLoS One 2013; 8: e57173.

28 Houdayer C, Caux-Moncoutier V, Krieger S et al: Guidelines for splicing analysis in molecular diagnosis derived from a set of 327 combined in silicolin vitro studies on BRCA1 and BRCA2 variants. Hum Mutat 2012; 33: 1228-1238.

29 Whiley $\mathrm{P}$, de la Hoya M, Thomassen $\mathrm{M}$ et al: Comparison of mRNA splicing assay protocols across multiple laboratories: recommendations for best practice in standardized clinical testing. Clin Chem 2014; 60: 341-352. 
30 Spurdle AB, Couch FJ, Hogervorst FB, Radice P, Sinilnikova OM: Prediction and assessment of splicing alterations: implications for clinical testing. Hum Mutat 2008; 29: 1304-1313.

31 Walker LC, Whiley PJ, Houdayer C et al: Evaluation of a 5-tier scheme proposed for classification of sequence variants using bioinformatic and splicing assay data: inter-reviewer variability and promotion of minimum reporting guidelines. Hum Mutat 2013; 34: 1424-1431.

32 Baralle D, Lucassen A, Buratti E: Missed threads. The impact of pre-mRNA splicing defects on clinical practice. EMBO Rep 2009; 10: 810-816.
33 Tammaro C, Raponi M, Wilson DI, Baralle D: BRCA1 exon 11 alternative splicing, multiple functions and the association with cancer. Biochem Soc Trans 2012; 40: 768-772.

(c) (1)(3) This work is licensed under a Creative Commons Ar ne sa Attribution-NonCommercial-ShareAlike 3.0 Unported License. To view a copy of this license, visit http://creative commons.org/licenses/by-nc-sa/3.0/

Supplementary Information accompanies this paper on European Journal of Human Genetics website (http://www.nature.com/ejhg) 